\title{
Udział organizacji pacjentów w kształtowaniu polityki ochrony zdrowia w Polsce - „koszmar partycypacji” czy remedium na "deficyt demokracji"?
}

\begin{abstract}
Streszczenie
Celem niniejszego artykułu jest analiza sektorowej polityki ochrony zdrowia w świetle zabezpieczenia interesu obywateli poprzez przybliżenie perspektywy zorganizowanych interesów organizacji pacjentów. Tekst jest próbą uzupełnienia dyskusji nt. roli tej szczególnej grupy interesariuszy w procesie podejmowania decyzji w sektorze ochrony zdrowia. Odwołując się do przykładów empirycznych, założono, że cały polski system ochrony zdrowia nie służy dobrze interesom pacjentów z powodu niedoborów organizacyjnych, finansowych i personalnych, a konstytucyjna obietnica równego dostępu do świadczeń ochrony zdrowia jest paradoksalnie skuteczną barierą dla wszelkich zmian zmierzających do poprawy sposobu funkcjonowania tego systemu. Pomimo wrażenia „zwrotu pacjentocentrycznego" w ochronie zdrowia w Polsce zorganizowane interesy pacjentów skupione wokół rzeczniczych organizacji pacjentów wciąż mają niewielki udział w procesie formułowania i wdrażania ważnych zmian w tej polityce sektorowej.
\end{abstract}

Słowa kluczowe: ochrona zdrowia, zorganizowane interesy, organizacje pacjentów, dostęp do opieki zdrowotnej, partycypacja

Klasyfikacja JEL: D71, D72, I14

DOI: $10.33119 / \mathrm{KSzPP} / 2020.3 .3$

\footnotetext{
1 Uniwersytet w Opolu, Szkoła Główna Handlowa w Warszawie, e-mail: ep79595@doktorant.sgh. waw.pl, https://orcid.org/0000-0002-8837-6824
} 


\title{
Participation of patient organizations in shaping the healthcare policy in Poland: "the nightmare of participation" or a remedy for the "democratic deficit"?
}

\begin{abstract}
The purpose of this article is to analyze the healthcare policy in the light of securing citizens' interests by bringing the perspective of patients' advocacy organizations. The paper tries to supplement the discussion on the role of this particular group of stakeholders in the decision-making process in the healthcare sector. Referring to empirical examples, the author assumes that the entire Polish healthcare system does not serve patients' interests well because of organizational, financial and personnel shortages, while the constitutional promise of equal access to healthcare services is paradoxically an effective barrier to any changes aimed at improving the way of functioning of the system. Despite the impression of a "patient-centered turn" in the healthcare policy in Poland, the organized interests of patients centered around advocacy organizations still have little impact on the process of formulating and implementing important changes in this sector policy.
\end{abstract}

Keywords: healthcare, organized interests, patients advocacy organizations, access to healthcare, participation

JEL Classification Codes: D71, D72, I14

Ochrona zdrowia jest wiecznie deficytową dziedziną polityki publicznej, co w oczywisty sposób prowadzi niejednokrotnie do niezadowolenia użytkowników systemu opieki zdrowotnej. Jednocześnie z uwagi na wzrost znaczenia praktyk partycypacyjnych w procesach decyzyjnych zagadnienie udziału pacjentów w kształtowaniu polityki zdrowotnej zyskuje na popularności, przykuwając uwagę badaczy na całym świecie (Guadagnoli, Ward, 1998; Mahoney, 2010).

Choć nie istnieje idealny system ochrony zdrowia i wiele państw boryka się z problemem niskiej partycypacji grup pacjentów, polscy pacjenci należą do jednych z najbardziej niezadowolonych z jakości i wydajności systemu opieki zdrowotnej wśród narodów europejskich. Warto przytoczyć tylko kilka podstawowych danych. W ostatnim zestawieniu Euro Health Consumer Index Polska plasuje się na czwartym miejscu od końca.

Wydaje się, że częste reformy systemu po 1989 r., w tym jego liczne instytucjonalne rekonfiguracje, nie zaowocowały wystarczająco pozytywnymi zmianami z perspektywy pacjentów pomimo prawa do ochrony zdrowia wprost zapisanego w art. 68 ust. 1 Konstytucji RP. Z badania przeprowadzonego przez Centrum Badania Opinii 
Społecznej (CBOS) w 2018 r. wynika, że 66\% Polaków negatywnie ocenia funkcjonowanie służby zdrowia w Polsce. Do najgorzej notowanych aspektów funkcjonowania opieki zdrowotnej zaliczono dostępność wizyt u specjalistów (83\% ocen negatywnych) oraz niewystarczającą liczbę personelu medycznego w szpitalach (70\%). Z kolei Najwyższa Izba Kontroli (NIK, 2019) przeanalizowała funkcjonowanie polskiego systemu ochrony zdrowia, opierając się na ustaleniach ponad 70 kontroli oraz na opiniach ekspertów. W ocenie Izby system nie jest przyjazny dla pacjenta.

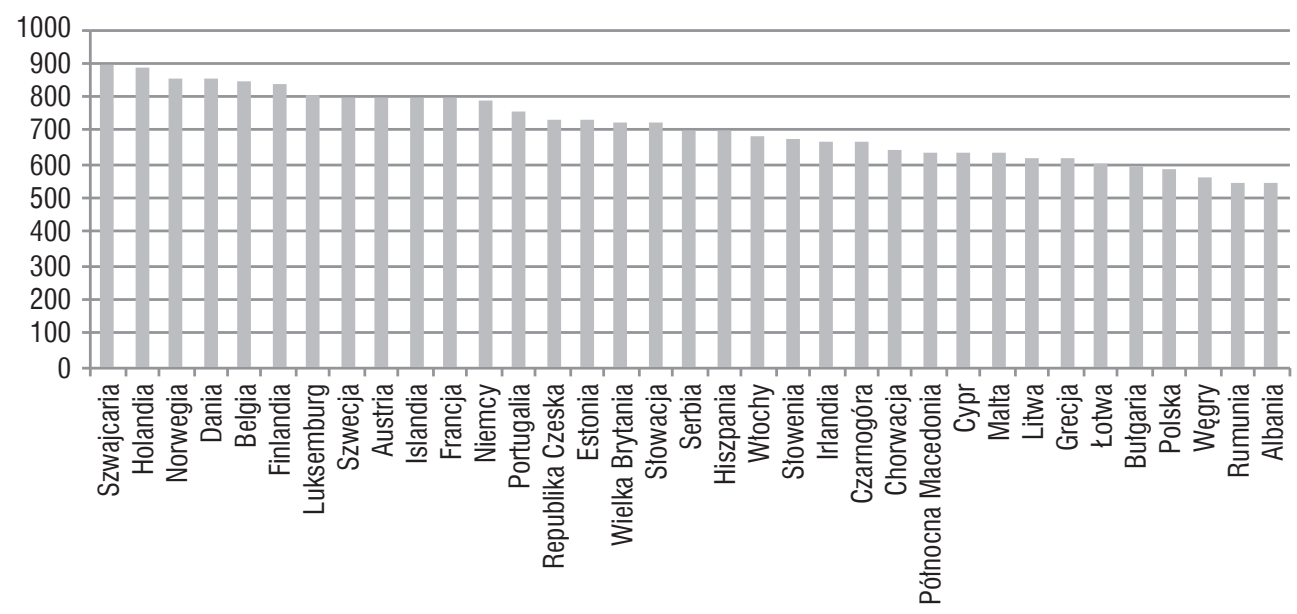

\section{Rysunek 1. Ranking EHCI - ocena funkcjonowania służby zdrowia w poszczególnych} krajach

Źródło: Health Consumer Powerhouse, 2019.

Niniejszy artykuł przybliża perspektywę polskich organizacji pacjentów w kontekście ich roli w kształtowaniu krajowej polityki zdrowotnej. Przedstawiono percepcję zagadnień systemowych oraz ocenę dostępu do organów decyzyjnych dokonaną przez przedstawicieli organizacji pacjentów. Założono, że system opieki zdrowotnej w Polsce nie jest „pacjentocentryczny”, tworzy nierówności, nie gwarantuje dostępności w sensownym terminie i nie jest wydolny według kluczowego kryterium, jakim jest zadowolenie pacjentów, a zatem użytkowników tego systemu.

Metodologicznie artykuł opiera się na analizie danych zastanych oraz wynikach 11 półustrukturyzowanych wywiadów pogłębionych, przeprowadzonych wiosną 2019 r. wśród przedstawicieli organizacji pacjentów w Polsce. Prócz wspomnianych badań jakościowych wykorzystano również pierwsze cząstkowe wyniki trwającego badania ilościowego w formie internetowej ankiety w programie LimeSurvey, prowadzonego wśród interesariuszy ochrony zdrowia, w tym także wśród organizacji pacjentów. Badanie jest realizowane w ramach międzynarodowego projektu badawczego 
pt. „Brakujące ogniwo w kreowaniu polityk w wybranych państwach postkomunistycznych" realizowanego przez Uniwersytet w Konstancji (Niemcy) i Uniwersytet Opolski (Polska) przy wsparciu finansowym Deutsche Forschungsgemeinschaft/Niemieckiej Fundacji Badawczej (DFG) i Narodowego Centrum Nauki (NCN). Kwestionariusz ankiety składa się z trzech bloków pytań otwartych i zamkniętych (z kafeterią odpowiedzi). Do udziału w badaniu zaproszono ogółem 306 interesariuszy. $\mathrm{Na}$ potrzeby niniejszej publikacji poddano cząstkowej analizie wyniki 18 odpowiedzi od przedstawicieli organizacji pacjentów, otrzymanych w 2019 roku.

\section{Historyczne uwarunkowania problemów sektora ochrony zdrowia}

Jak wskazują przytaczane badania statystyczne, liczne organizacyjno-prawne korekty systemu opieki zdrowotnej przeprowadzane od lat dziewięćdziesiątych ubiegłego wieku nie znalazły odzwierciedlenia w takiej jego sprawności, która satysfakcjonowałaby użytkowników. Tymczasem rośnie inflacja w zdrowiu, brakuje kadr medycznych, a społeczeństwo się starzeje. Wyzwania demograficzne powodują wzrost wydatków na opiekę zdrowotną i społeczną oraz świadczenia emerytalne. Rosnące potrzeby finansowania służby zdrowia to także skutek jej zwiększającej się kapitałochłonności, coraz większych kosztów terapii farmakologicznych oraz coraz lepszej diagnostyki, umożliwiającej wykrycie chorób i determinującej walkę z nimi. W tym świetle konstytucyjny zapis o równym i powszechnym prawie do opieki zdrowotnej w dużej mierze wydaje się fikcją.

Społeczne oczekiwania wobec systemu ochrony zdrowia w Polsce mają stosunkowo długą tradycję. W okresie międzywojennym przyjęto model Bismarckowski, zwany też ubezpieczeniowym, który był w różnych wariantach replikowany w wielu państwach Europy międzywojennej, w tym także w Polsce (Leowski, 2009). Ubezpieczeniem zdrowotnym finansowanym ze składek pracowników i pracodawców obejmowane były różne grupy zawodowe (Makarzec, 2012; Grata, 2013). Po II wojnie światowej, w warunkach gospodarki socjalistycznej, system przynajmniej w teorii gwarantował wszystkim obywatelom bezpłatną, powszechną opiekę lekarską - choć finansowaną z budżetu centralnego, odwrotnie niż w modelu ubezpieczeniowym.

Transformacja systemu politycznego i ekonomicznego w Polsce po $1989 \mathrm{r}$. wywołała przeobrażenia także w sektorze ochrony zdrowia: stopniowo odchodzono od modelu budżetowego na rzecz powrotu do modelu budżetowo-ubezpieczeniowego. Z powodu gwałtownego spadku dochodów realnych społeczeństwa, bezrobocia, likwidacji dotacji do cen czy właśnie odejścia państwa od pełnego pokrywania 
kosztów opieki zdrowotnej poziom bezpieczeństwa socjalnego Polaków uległ obniżeniu (Skrzypczak, 2013). Reformę systemu ochrony zdrowia przeprowadzano stosunkowo opieszale w porównaniu z dynamicznymi zmianami innych sfer życia społeczno-gospodarczego: jeszcze przez prawie dekadę po 1989 roku system ochrony zdrowia funkcjonował w tzw. modelu Siemaszki, typowym dla państw socjalistycznych (Rabiej, 2017).

W ustawie zasadniczej Rzeczypospolitej Polskiej z 1997 roku zapisano równy dostęp do opieki zdrowotnej. Zapis znalazł się w rozdziale II, określającym wolności, prawa i obowiązki. Przyjął on następujące brzmienie:

„Art. 68.

1. Każdy ma prawo do ochrony zdrowia.

2. Obywatelom, niezależnie od ich sytuacji materialnej, władze publiczne zapewniają równy dostęp do świadczeń opieki zdrowotnej finansowanej ze środków publicznych. Warunki i zakres udzielania świadczeń określa ustawa.

3. Władze publiczne są obowiązane do zapewnienia szczególnej opieki zdrowotnej dzieciom, kobietom ciężarnym, osobom niepełnosprawnym i osobom w podeszłym wieku.

4. Władze publiczne są obowiązane do zwalczania chorób epidemicznych i zapobiegania negatywnym dla zdrowia skutkom degradacji środowiska.

5. Władze publiczne popierają rozwój kultury fizycznej, zwłaszcza wśród dzieci i młodzieży".

Towarzysząca reformie administracyjnej z 1999 roku reforma ochrony zdrowia zakładała przekazanie samorządom znacznej części obowiązków związanych z udzielaniem świadczeń. Decentralizacja zadań spowodowała jednak de facto rozmycie odpowiedzialności, a niedobór środków finansowych skutkował ograniczeniem dostępności do usług, wywołującym niezadowolenie pacjentów. Niejako na marginesie tego niezadowolenia postępował wpisany w reformę proces prywatyzacji części usług, na przykład w podstawowej opiece zdrowotnej czy stomatologii (Wieloch, 2011). Postępujące niezadowolenie i naciski polityczne doprowadziły w 2004 roku do kolejnej reformy i centralizacji środków w rękach jednej instytucji: publicznego płatnika pod postacią Narodowego Funduszu Zdrowia. Z perspektywy samych użytkowników systemu - pacjentów - przeprowadzane reformy niewiele zmieniały. Obowiązkowy wkład w system nie gwarantował dostępności ani wysokiego poziomu świadczenia opieki zdrowotnej. Świadczeniodawcy byli i w większości procedur nadal są limitowani wielkością środków od publicznego płatnika. W rezultacie pacjenci mieli i mają do czynienia z tymi samymi trudnościami co we wcześniejszym modelu państwowym. 
Potwierdzają to wyniki kontroli przeprowadzonych przez Najwyższą Izbę Kontroli, która konkluduje we wspomnianym wystąpieniu, że dostęp do usług medycznych uzależniony jest od sytuacji ekonomicznej pacjenta. Z raportu wynika także, że polscy pacjenci są zmuszeni do długiego oczekiwania w kolejkach po diagnostykę i specjalistyczne swiadczenia, co nierzadko skutkuje koniecznością sięgnięcia do prywatnego portfela. Pacjentom brakuje informacji na temat jakości leczenia, a sama jakość jest niewystarczająco premiowana w procesie przyznawania środków na leczenie placówkom opieki zdrwotnej. Izba zwróciła również uwagę na brak równego dostępu pacjentów do świadczeń: dostęp ten jest ograniczony i nierównomierny terytorialnie. Opublikowany raport mówi wręcz o zagrożeniach dla pacjentów, jakie płyną z korzystania z publicznej oferty, takich jak zakażenia szpitalne, niewystarczające doświadczenie podmiotów leczniczych czy podejmowanie leczenia bez przeprowadzenia pełnej dianostyki.

\section{Pacjenci jako szczególna grupa interesariuszy}

Dziś, mimo postępującego udziału wydatków out-of-pocket w całkowitych wydatkach na zdrowie, oczekiwania społeczeństwa polskiego co do poziomu zabezpieczenia zdrowotnego przez publiczny system są wciąż stosunkowo wysokie. Warto więc zapytać, czy konstytucyjnie zagwarantowany dostęp do opieki zdrowotnej (uznanej za uniwersalną, publicznie dostępną, równą i finansowaną ze środków publicznych) faktycznie służy interesom pacjentów, czy raczej, paradoksalnie, może przynosić efekt odwrotny do zamierzonego, stanowiąc barierę dla wdrażania potrzebnych reform systemowych.

System opieki zdrowotnej jest tak skonstruowany, że formalnie zapewnia równy dostęp do świadczeń opieki zdrowotnej, który opiera się na powszechnym obowiązkowym ubezpieczeniu. Tymczasem jego elementarne braki zmuszają większość pacjentów do korzystania w sferze prywatnej z tych samych usług, za które płacą w ramach składki. Prywatni dostawcy nie uzupełniają systemu publicznego, lecz replikują go, tworząc sytuację, w której pacjenci płacą dwa razy nawet za podstawowe świadczenia opieki zdrowotnej (tzw. „ukryte współpłacenie”). Z drugiej strony zapisy konstytucyjne i ich populistyczna interpretacja stosowana przez niektóre media oraz adwersarzy politycznych uniemożliwiają publiczną dyskusję na temat wprowadzenia jakiejkolwiek istotnej reformy systemu mającej na celu poprawę dostępności do usług opieki zdrowotnej. Dość wspomnieć, że ostatni konkretny projekt legislacyjny w sprawie wprowadzenia do systemu dodatkowych ubezpieczeń zdrowotnych upadł niemal dekadę temu. 
Organizacje pozarządowe, w tym organizacje pacjentów, mają coraz większy udział w kształtowaniu ochrony zdrowia na szczeblu unijnym. W ostatnich latach głos pacjentów uległ istotnemu wzmocnieniu także w Polsce. Fundacje i stowarzyszenia oraz mniej sformalizowane grupy nacisku reprezentujące interes pacjentów biorą aktywny udział w procesie legislacyjnym, tworzą narrację wokół kluczowych zagadnień ochrony zdrowia, wpływając na opinię publiczną, odgrywają też niebagatelną rolę przy wydawaniu decyzji administracyjnych dotyczących refundacji technologii lekowych. Czy rzeczywiście jednak możemy mówić o zwrocie pacjentocentrycznym w polskim systemie ochrony zdrowia? Czy mamy do czynienia z odpowiedzią na „deficyt demokracji”, czy raczej „koszmarem partycypacji”, o którym pisał Markus Miessen podający w wątpliwość trend powszechnej, ślepej wręcz partycypacji społecznej i argumentujący, że tak naprawdę niejednokrotnie staje się ona przyczynkiem do zastoju (Miessen, 2013)? Czy postępująca profesjonalizacja organizacji pacjentów przekłada się w Polsce na ich realną sprawczość?

Obecnie w Polsce działa ok. 6000 organizacji pacjenckich, co stanowi 8\% wszystkich organizacji pozarządowych (Klon/Jawor, 2019). Analiza wywiadów pogłębionych z przedstawicielami organizacji pacjentów z całego kraju pokazuje, że główne bolączki, z jakimi mierzą się obecnie organizacje pacjenckie, to brak środków finansowych, które umożliwiałyby profesjonalizację działań i uniezależnienie od środków przekazywanych przez przemysł farmaceutyczny. Nawet jeśli organizacji udaje się wypracować profesjonalną wiedzę ekspercką, jest ona wykorzystywana przez decydentów i wdrażana bez udziału grup zaangażowanych w jej powstanie.

Zgodnie z klasyczną myślą Olsona (1965) o logice zbiorowego działania stopień koncentracji, rozmiar i obszar zainteresowań danej grupy determinują jej zdolność do osiągania celów oraz dostęp do procesu decyzyjnego i samych decydentów. Nie do końca przy tym istotny jest tu rozmiar danej grupy interesów: te mniejsze, a bardziej skoncentrowane są skuteczniejsze i bardziej uprzywilejowane niż nawet większe, ale rozproszone. Teoria Olsona wydaje się mieć zastosowanie także w przypadku badania wpływu organizacji reprezentujących interes obywateli-pacjentów na proces decyzyjny. Ochrona zdrowia, pozostając jedną z kluczowych dziedzin polityki publicznej oraz ważnym przedmiotem zainteresowania opinii publicznej i społeczeństwa, jest niedofinansowana i stanowi pole walki dla interesów wielu grup interesariuszy. Część z nich jest skrajnie rozproszona (jak głos obywateli skupionych w licznych i słabych organizacjach pacjentów), część zaś przeciwnie - silnie skorporatyzowana (jak na przykład samorządy zawodowe personelu medycznego, z zapleczem finansowym, eksperckim, o dużo wyższym stopniu organizacji i profesjonalizacji). 


\section{Ocena funkcjonowania systemu i zabezpieczenia zdrowotnego}

W badaniu ilościowym kwestie oceny funkcjonowania samego systemu czy zabezpieczenia interesów pacjentów przez obecny system nie zostały poruszone. Posiłkowano się więc wynikami rozmów z przedstawicielami organizacji pacjentów. Wywiady na potrzeby niniejszego artykułu powstały w ramach jakościowego badania wpływu wybranych interesariuszy na proces decyzyjny wokół kwestii poprawy publicznego finansowania systemu ochrony zdrowia, niemniej część pytań dotyczyła bezpośrednio oceny funkcjonowania systemu, kwestii nierówności w zdrowiu, dostępu konkretnych grup terapeutycznych do leczenia oraz dostępu do procesu decyzyjnego.

Zasadniczo wszyscy rozmówcy przyznawali, że system nie zabezpiecza interesu pacjenta, i podkreślali słaby status zabezpieczenia zdrowotnego na różnych etapach: od diagnozy przez leczenie po opiekę po terapii. Jednocześnie prawie żaden rozmówca nie wyraził konkretnego zdania na temat pożądanego sposobu zmiany funkcjonowania systemu w aspektach finansowych czy organizacyjnych. Przedstawiciel pacjentów reprezentujący osoby $\mathrm{z}$ chorobami rzadkimi nazwał ścieżkę pacjenta wręcz „odyseją diagnostyczną” (W/12/06/2019/2). Inni pacjenci, z którymi przeprowadzono wywiady, stwierdzali często, że czują się niedoinformowani w relacji z lekarzem, a wręcz, że byli traktowani jak „niegrzeczne dziecko” (W/13/06/2019).

Ciekawym aspektem nierówności było rozróżnienie na pacjentów, których schorzenia są lepiej lub gorzej wyceniane przez system. Kilka osób wprost podkreśliło, że istnieje instytucjonalna dyskryminacja wybranych grup pacjentów: na przykład z zakresu geriatrii, psychologii, psychiatrii lub pediatrii. Jednocześnie są to najsłabsze grupy pacjentów, bez formalnej reprezentacji i silnego głosu w dostępie do opinii publicznej i decydentów. Te grupy „cierpią w milczeniu” (W/15/05/2019; W/21/05/2019; W/18/06/2019).

Zaledwie jedna z jedenastu osób, z którymi udało się odbyć rozmowy, wykazywała większe zainteresowanie kwestiami systemowymi i była $\mathrm{w}$ stanie zasugerować konkretne zmiany organizacji całego systemu opieki zdrowotnej w Polsce, a nie tylko jego fragmentu. Na pytanie dotyczące finansowania systemu rozmówcy odpowiadali wielorako: niektórzy wykazywali przekonanie, że słabe finansowanie jest problemem („Wierzę, że podniesienie składki jest konieczne, aby usprawnić funkcjonowanie systemu”, W/15/05/2019), inni - że obecny stan finansowania jest wystarczający: „100 mln zł wydatkowane rocznie na opiekę zdrowotną w zupełności wystarczy. Problemem jest niewłaściwa alokacja środków. Być może zbyt szybko zlikwidowaliśmy 
kasy chorych, wylewając dziecko z kąpielą?” (W/28/05/2019); „Prawdziwym problemem jest brak zaufania na linii pacjent-lekarz. Tego nie da się kupić za żadne pieniądze" (W/28/06/2019).

\section{Profesjonalizacja i zasoby organizacji}

W ramach przeprowadzonej ankiety internetowej organizacje pacjentów odpowiedziały na wiele pytań dotyczących kwestii organizacyjnych (takich jak charakter członkostwa czy rozmiar organizacji) oraz wynikających z nich zasobów osobowych, finansowych czy rzeczowych. Połowa respondentów przyznała, że organizacja ma członków. Biorąc pod uwagę fakt, że organizacje pozarządowe w Polsce mogą przyjmować charakter nieformalnej inicjatywy bądź sformalizowanej fundacji lub stowarzyszenia (to drugie może zrzeszać członków), tę zmienną uznano za nieistotną.

Poświęcono jednak pewną uwagę kwestii przynależności do większej organizacji. Spośród respondentów $22 \%$ zadeklarowało członkostwo w narodowej organizacji parasolowej, 27\% zadeklarowało członkostwo w międzynarodowej organizacji parasolowej. Połowa respondentów zadeklarowała kontakty z przynajmniej jedną zagraniczną organizacją pacjentów. W ramach odpowiedzi na ankietę wśród wymienianych korzyści płynących z członkostwa w organizacji parasolowej (jako pozytywnego skutku procesu europeizacji) pojawiały się: transfer wiedzy i doświadczenia (55\% odpowiedzi), udział w warsztatach edukacyjnych (44\%), lepszy wpływ na krajowy proces agenda-setting (27\%), możliwość opracowywania wspólnych stanowisk merytorycznych czy postulatów (16\%) czy pozyskiwanie finansowania od organizacji o parasolowym charakterze (zaledwie 5\%). Wynika z tego, że korzyści te mają w przeważającej skali niematerialny charakter, natomiast można mówić o wielkim wpływie członkostwa na profesjonalizację merytoryczną organizacji. Potwierdzają to przeprowadzone badania jakościowe. Jak stwierdził jeden $\mathrm{z}$ informatorów podczas wywiadu: „Dzięki naszemu kontaktowi z organizacją partnerską na poziomie UE zaczęliśmy wierzyć, że wzmocnienie pozycji pacjenta nie jest pustym wyrażeniem, ale pacjenci naprawdę mogą mieć pewien wpływ na podejmowanie decyzji” (W/15/05/2019). Co istotne, zdolność do wytwarzania wiedzy eksperckiej przez organizacje dotyczy wąskich obszarów, takich jak opieka nad pacjentami z danym problemem terapeutycznym.

W ramach badania ilościowego przedstawiciele organizacji zostali poproszeni o ocenę stabilności finansowej w perspektywie roku, dwóch, trzech-pięciu i ponad pięciu lat. Znakomita większość mogła planować swoje wydatki tylko w krótkoterminowej perspektywie roku (22\% organizacji) lub dwóch (27\%). Zaledwie jedna 
organizacja zadeklarowała możliwość planowania w perspektywie ponad pięciu lat. Dane z wywiadów dowodzą dodatkowo, że głównym problemem jest brak finansów pozwalających na profesjonalizację i długoterminowe uniezależnienie od środków od przemysłu farmaceutycznego. Odnośnie do kwestii środków finansowych na działalność większość rozmówców w wywiadach podkreślała konieczność rywalizacji (o $1 \%$ podatku w przypadku organizacji pożytku publicznego (OPP) czy finanse otrzymywane od firm farmaceutycznych), która uniemożliwia lub utrudnia zawiązywanie strategicznych sojuszy. Jeden z rozmówców przyznał, że głównym powodem wzajemnej niechęci organizacji jest fakt rywalizacji o te same środki: „Nawet jeśli współpracujemy z innymi organizacjami onkologicznymi merytorycznie, jednocześnie jesteśmy zmuszeni rywalizować o finanse, co wzmaga atmosferę wzajemnej nieufności" (W/7/06/2019).

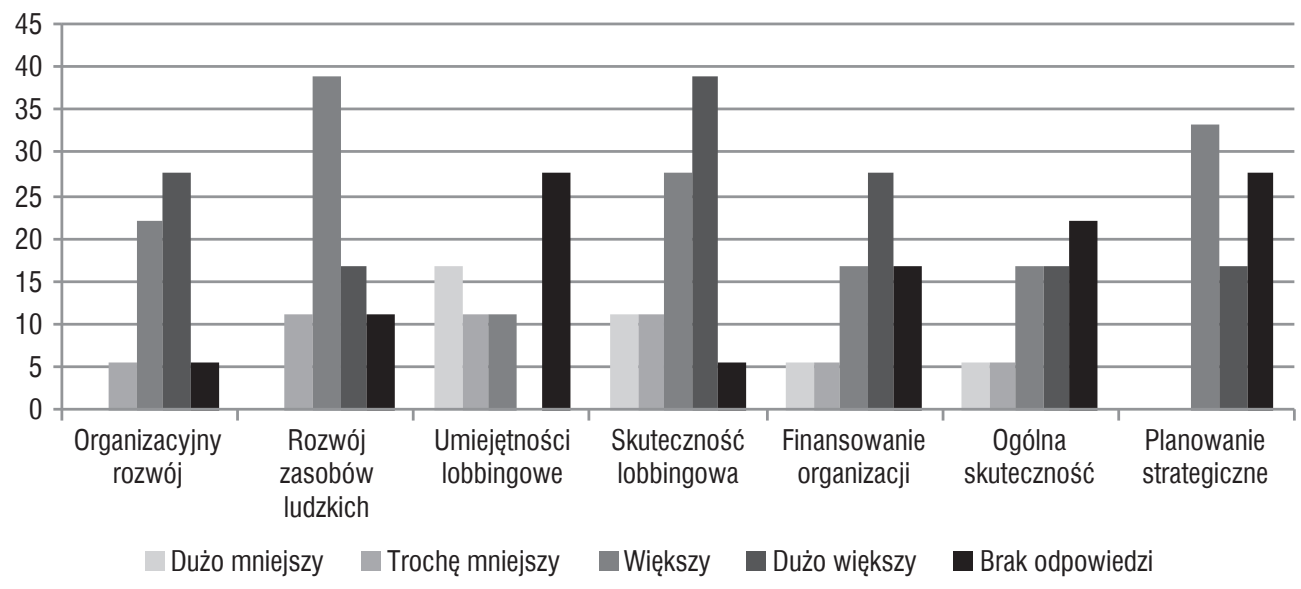

Rysunek 2. Ocena profesjonalizacji grup interesów w porównaniu z latami ubiegłymi $\mathrm{z}$ uwagi na wybrane kryteria (zmienna "skupienie na danym aspekcie profesjonalizacji”" na 5-stopniowej skali od 1 do 5) (w \%)

Źródło: opracowanie własne.

Aspekty profesjonalizacji zostały w badaniu ilościowym sprawdzone poprzez zadanie pytań o ocenę skupienia na wybranych aspektach rozwoju w porównaniu z latami ubiegłymi. Kryteria tej samooceny dotyczyły rozwoju organizacyjnego, rozwoju zasobów ludzkich, zdolności lobbingowych, efektywności działań lobbingowych, gromadzenia zasobów finansowych, ogólnej skuteczności czy planowania strategicznego. Poproszono organizacje o ocenę tych czynników na pięciostopniowej skali: od „dużo mniejszych” przez „mniejsze”, „takie same” po „większe” i „dużo większe". Połowa organizacji określiła stan swojego rozwoju organizacyjnego jako 
„taki sam”. Zbadane zostały również zasoby ludzkie organizacji. Te prezentują się dość optymistycznie: $38 \%$ organizacji, które wypełniły ankietę, przyznało, że zatrudnia pracowników. Tylko 5\% zadeklarowało brak wolontariuszy. Aż 55\% organizacji stwierdziło, że „większy” nacisk kładzie na rozwój zasobów ludzkich, w tym 16\% „dużo większy”. „Taki sam” focus na pozyskiwanie finansów jak kilka lat wcześniej wskazało $27 \%$ organizacji, a w sumie aż $44 \%$ organizacji podało, że jest on „większy” lub nawet „dużo większy”.

Zapytane w ankiecie o umiejętności lobbingowe zaledwie dwie organizacje przyznały, że są one „większe”. Ani jedna nie oceniła ich jako „dużo większych”, przy czym aż $27 \%$ uchyliło się od odpowiedzi. Jednocześnie, jeśli chodzi o skuteczność podejmowanych działań, znakomita większość ankietowanych określiła swoją skuteczność lobbingową jako „większą” (27\%) czy nawet „dużo większą” (38\% odpowiedzi).

\section{Dostęp do procesu decyzyjnego}

Pytani w wywiadach o „zwrot pacjentocentryczny” w Polsce pacjenci przyznawali, że organizacje częściej zapraszane są do różnych ciał dialogu społecznego, na posiedzenia parlamentarne, spotkania $\mathrm{z}$ resortem zdrowia w sprawie poprawy sytuacji danych grup. Wybrani podkreślali jednocześnie, że nie są traktowani na takich samych zasadach jak inni eksperci, np. ze środowiska lekarskiego. Przykładowo, jeden z rozmówców wyznał: „To jest nierówna walka. Nawet jeśli jesteśmy jako pacjenci zapraszani na to samo spotkanie, nie mamy zapewnionego zwrotu kosztów transportu jak inni eksperci z personelu medycznego" (W/12/06/2019/2). Część rozmówców sugerowała, że włączanie przedstawicieli pacjentów do procesu stanowienia prawa ma charakter fasadowy („Oni - decydenci - biorą nasze podpowiedzi i wdrażają je. Bez konsultacji z nami. W rezultacie patrzymy, jak dobre pomysły marnują się przez niewłaściwą implementację", W/12/06/2019/2). W kwestii dostępu do decydentów rozmówcy podkreślali, że politycy są otwarci na spotkania głównie przed wyborami (W/15/05/2019; W/07/06/2019; W/20/06/2019). Jeden z rozmówców wyraził wręcz niemoc w zakresie dostępu do procesu podejmowania decyzji, mówiąc „Czuję, jakbym walił głową w mur” (W/28/06/2019).

Jeśli chodzi o dostęp do polityków, 44\% respondentów zadeklarowało kontakt z partiami politycznymi, 33\% utrzymuje kontakty zarówno ze stroną rządzącą, jak i opozycją. Aż $72 \%$ respondentów zadeklarowało kontakt $\mathrm{z}$ administracją publiczną. Relatywnie dobry okazał się dostęp pacjentów do parlamentu: aż 44\% respondentów opisało go jako „czasem możliwy”, a prawie 28\% jako „łatwy” i „bardzo łatwy”. 


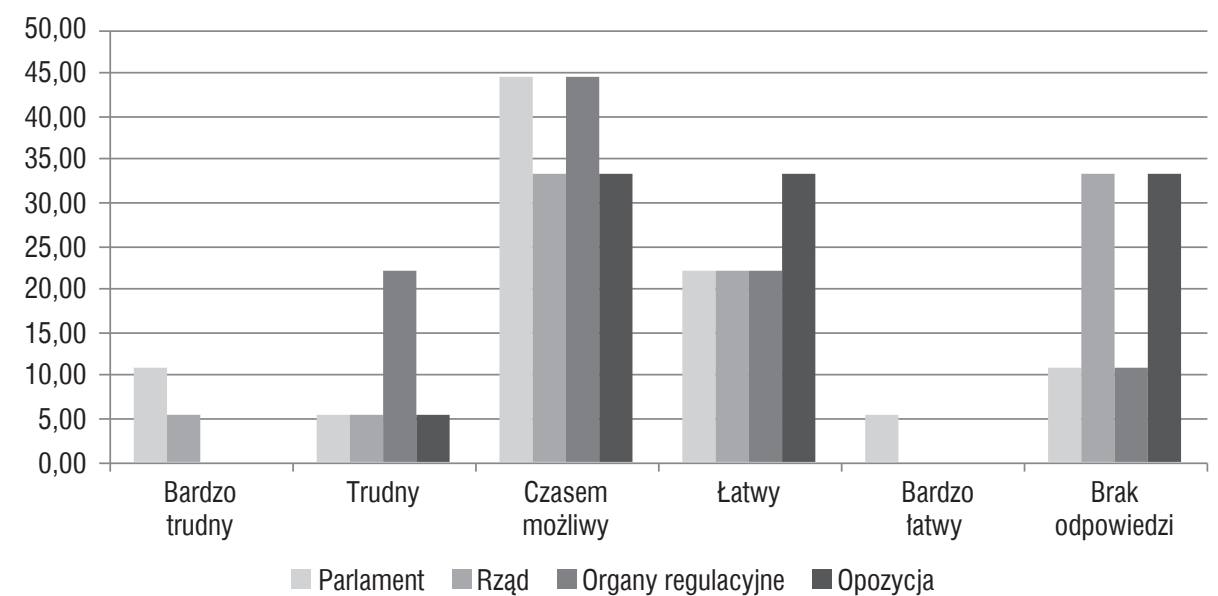

Rysunek 3. Ocena dostępu grup interesów do poszczególnych ciał decyzyjnych (zmienna „dostęp" na 5-stopniowej skali od 1 do 5) (w \%)

Źródło: opracowanie własne.

W kwestii samej potrzeby partcypacji organizacji pacjentów w kształtowaniu polityki zdrowotnej zdania rozmówców były podzielone. Część twierdziła, że to nie pacjenci, ale politycy powinni proponować zmiany systemowe. Jak powiedział jeden z przedstawicieli środowiska: „Państwo powinno zacząć wypełniać swój obowiązek zagwarantowany w Konstytucji i zapewnić bezpłatny dostęp do wszystkich usług zdrowotnych dostępnych zgodnie z najnowszą wiedzą medyczną" (W/13/06/2019). Inny rozmówca przyznał, że „konieczna jest reforma systemowa i należy ją szybko wprowadzić, ponieważ brakuje już personelu medycznego. Dlatego oferta publiczna wkrótce się rozpadnie" (W/28/05/2019). Odwrotne podejście prowadzi do założenia, że pacjenci powinni wziąć na siebie odpowiedzialność, proaktywnie proponując zmiany systemowe: „Postanowiłem działać natychmiast. Zatrudniliśmy eksperta, aby opracował wniosek ustawodawczy w sprawie prawa dotyczącego przeszczepów. Został z powodzeniem przyjęty i po tylu latach nadal działa” (W/12/06/2019).

Zdaniem rozmówców, w wielu przypadkach atmosfera rywalizacji i braku zaufania między organizacjami pacjentów, która uniemożliwia zawiązywanie strategicznych partnerstw, powoduje brak formalnej reprezentacji tych grup w największych, systemowych dyskusjach. Jeden z rozmówców przyznał: „Tak długo, jak będziemy rozproszeni i skłóceni, nie będziemy mówić wspólnym głosem, a decydenci będą mieli dobry pretekst, żeby nasz głos ignorować” (W/21/05/2019). Problem wiarygodności i reprezentacji okazał się istotnym aspektem dyskusji o dostępie do procesu decyzyjnego: występuje kwestia rozproszonego interesu. Prawie wszystkie organizacje skupiają się na konkretnych grupach terapeutycznych. Nawet największa organizacja 
pacjentów w kraju zadeklarowała w wywiadzie brak ambicji na polu reprezentacji wszystkich obywateli jako największej grupy pacjentów. Co istotne, wielkość i liczba członków ma znaczenie: organizacje z małą liczbą członków próbujące „grać” reprezentatywność, są automatycznie stygmatyzowane przez inne.

$$
* * *
$$

Celem niniejszej pracy było przybliżenie perspektywy zorganizowanych interesów pacjentów w kontekście dostępu i poczucia wpływu reprezentantów organizacji rzeczniczych pacjentów na kształtowanie polityki zdrowotnej w Polsce.

Wydaje się, że wobec ograniczonej ilości środków w budżecie, co skutkuje utrudnieniami w dostępie obywateli do świadczeń, zasada równego dostępu do świadczeń opieki zdrowotnej w dużym stopniu jest fikcją. Równość zapisana w Konstytucji oznacza, że chorzy powinni otrzymywać terapie na podstawie swoich potrzeb zdrowotnych, a nie czynników pozazdrowotnych, jak zasobność portfela. Tymczasem z uwagi na niedobór środków w systemie pacjenci są skazani na czekanie w długich kolejkach po świadczenia czy korzystanie z odpłatnego systemu niepublicznego. Ta systemowa inercja znajduje swoje odzwierciedlenie w rankingach (nie) zadowolenia pacjentów. Wyjściem wydaje się wprowadzenie ustawowych rozwiązań umożliwiających pozyskiwanie przez państwo środków publicznych na ten cel, takich jak legalne współpłacenie, dodatkowe ubezpieczenia zdrowotne czy wyznaczenie kwot maksymalnych, powyżej których opłatę za świadczenie pokrywa państwo. Zdaniem konstytucjonalistów takie zapisy nie stałyby w sprzeczności z ustawą zasadniczą, o ile respektowany byłby przy ich wprowadzeniu rygor utrzymania równego dostępu do świadczeń dla osób opłacających niższe składki na ubezpieczenie zdrowotne. Jak pisze M. Urbaniak (2013), „z konstytucyjnej zasady równości nie wynika obowiązek zapewnienia przez władzę publiczną bezpłatnej, a jedynie równej dla wszystkich obywateli opieki zdrowotnej, która musi być zagwarantowana ze środków publicznych. Powszechnym wśród pacjentów błędem jest utożsamianie zapisów konstytucyjnych z obowiązkiem bezpłatnego zapewniania świadczeń przez państwo. W rezultacie społeczne rozczarowanie tylko wzrasta, a jakakolwiek dyskusja o wprowadzeniu pewnych odpłatności przez pacjentów wydaje się niemożliwa.

System nie służy zatem w pełni interesom pacjentów, ale i sami pacjenci mają „do odrobienia” ważną lekcję. Postawiona na wstępie teza o tym, że system opieki zdrowotnej w Polsce nie jest „pacjentocentryczny”, tworzy nierówności, a same organizacje pacjentów nie mają wystarczającego wpływu na kształt systemu, znajduje potwierdzenie. Mając na uwadze zawodność prób mierzenia wpływu, w niniejszym tekście poddano analizie kwestie dostępu organizacji pacjentów do ciał decyzyjnych. Dostęp ten został przedstawiony na tle problematyki zasobów organizacji, 
ponieważ zdaniem zdecydowanej większości naukowców to właśnie one stanowią czynnik warunkujący zdolność organizacji do uczestnictwa w procesie kształtowania polityki publicznej (Dür, De Bièvre, 2007).

Organizacje rzecznicze pacjentów cieszą się stosunkowo dobrym dostępem do ciał wykonawczych i parlamentu. Organizacje pacjentów biorą udział w procesie legislacyjnym, zabierając głos w ważnych sprawach ochrony zdrowia i próbując wpływać na opinię publiczną. Część reprezentantów bierze nawet udział w zorganizowanych ciałach doradczych przy resorcie zdrowia czy Kancelarii Prezydenta RP. Są obecni w mediach tradycyjnych i społecznościowych. Dość wspomnieć, że bardzo niewiele z nich wskazało w badaniu ilościowym na trudność w dostępie do decydentów, tymczasem większość określiła ten dostęp jako przynajmniej okazjonalnie możliwy. Odnotowano także istotny wzrost poczucia ogólnej skuteczności podejmowanych działań. Mimo to organizacje nie wzmocniły znacznie swojej profesjonalizacji w stosunku do lat ubiegłych. Najsilniejszymi aspektami profesjonalizacji w samoocenie respondentów był rozwój zasobów ludzkich, planowanie strategiczne i finansowanie organizacji rozumiane jako rozwój zdolności fundraisingowych. Co istotne, nie przełożyło się to na stabilność sytuacji finansowej organizacji, która dalej planowana jest w krótkoterminowej perspektywie. Relatywnie małe było też zadeklarowane uczestnictwo w ponadnarodowych organizacjach parasolowych.

Wydaje się, że ze względu na uwarunkowania historyczne i późniejszy rozwój społeczeństwa obywatelskiego w krajach postkomunistycznych, takich jak Polska (Howard, 2003), grupy rzeczników pacjentów nie rozwinęly jeszcze odpowiedniej siły organizacyjnej, zasobów i narzędzi do poważnego uczestnictwa. Jak wynika z badania jakościowego, z roku na rok stają się silniejsze i coraz intensywniej komentują zmiany systemowe wprowadzone przez rząd, niemniej nie mają jeszcze motywacji i odpowiedniej wiedzy eksperckiej, aby zaproponować spójną reformę, która miałaby na celu wzmocnienie pozycji pacjenta $\mathrm{w}$ całym systemie zgodnie $\mathrm{z}$ realizacją obietnic konstytucyjnych.

Wydaje się, że pomimo relatywnie dobrego dostępu do decydentów realny wpływ organizacji jest niewielki. Konsumenci systemu - pacjenci - są ekstremalnie rozproszoną grupą w porównaniu z profesjonalnym, skoncentrowanym interesem innych grup interesariuszy. Powracając w konkluzji do myśli Olsona, w świetle skrajnie rozproszonych interesów pacjentów wydaje się, że to nie zalecenia opracowane przez organizacje rzecznicze pacjentów, ale ogólne tendencje reform społeczno-gospodarczych, wytyczane głównie przez inne grupy interesariuszy (na przykład wybrane grupy personelu medycznego), określają kierunki ewolucji systemu opieki zdrowotnej. Przykładowo, o wzrost publicznych nakładów na ochronę zdrowia zawalczyli skutecznie raczej lekarze rezydenci. 
Podsumowując, organizacje pacjentów w Polsce mają jeszcze dużą przestrzeń do poprawy w zakresie wzmocnienia profesjonalizacji, legitymacji i wiedzy. Cechuje je skupienie raczej na małych kwestiach dedykowanych danym obszarom terapeutycznym i refundacji niż na dużych systemowych tematach. Nawet jeśli czują, że ich skuteczność jest większa niż kiedykolwiek, i cieszą się relatywnie dobrym dostępem do organow decyzyjnych, w większości przypadków nie są w stanie wypracować eksperckiego stanowiska w kwestii upodmiotowienia pacjenta czy nawet większych zmian systemowych. Dodatkowo, nie są traktowane przez decydentów jak równy, profesjonalny partner w debacie i formułowaniu polityki. Jak wskazali respondenci w wywiadach pogłębionych, niekończące się reformy systemu opieki zdrowotnej, jego elementów oraz fundamentów strukturalnych, nie spowodowały istotnych zmian jakościowych z perspektywy pacjentów. Wciąż czują się oni najsłabszym z ogniw ekosystemu i, jak pokazują międzynarodowe badania satysfakcji pacjentów, nie wykorzystują swojego prawa do współdecydowania w równym stopniu co obywatele innych krajów europejskich (Borek, Chwiałkowska, 2014). Być może kontynuacja prowadzonych badań przyniesie więcej informacji na temat przyczynowych i systemowych aspektów tej niemocy.

\section{Bibliografia}

Borek, E., Chwiałkowska, A. (2014). Partycypacja pacjentów w pocesie podejmowania decyzji w ochronie zdrowia w Polsce. Journal of Health Sciences, 4(1): 289-296.

CBOS (Centrum Badania Opinii Społecznej) (2018). Opinie na temat funkcjonowania opieki zdrowotnej w Polsce, https://www.cbos.pl/SPISKOM.POL/2018/K_089_18.PDF (dostęp: 20.10.2019).

Czapiński, J., Panek, T. (red.), Diagnoza Społeczna, http://www.diagnoza.com/ (dostęp: 29.03.2019).

Dür, A., De Bièvre, D. (2007). Inclusion without Influence: NGOs in European Trade Policy. Journal of Public Policy, 27(1): 79-101.

Grata, P. (2013). Polityka społeczna Drugiej Rzeczypospolitej. Rzeszów: Wydawnictwo Uniwersytetu Rzeszowskiego.

Guadagnoli, E., Ward, P. (1998). Patient participation in decision-making. Social Science $\triangleleft$ Medicine, 47(3): 329-339. DOI: 10.1016/S0277-9536(98) 00059-8.

Health Consumer Powerhouse (2019). Ranking Euro Health Consumer Index, https://healthpowerhouse.com/publications/ (dostęp: 29.03.2019).

Howard, M.D. (2003). The Weakness of Civil Society in Post-Communist Europe. Cambridge: Cambridge University Press. 
Ilnicka-Jordan, P. (2016). Realizacja zadań z dziedziny ochrony zdrowia jako obowiązek organów władzy publicznej w Rzeczypospolitej Polskiej, w: Zadania publiczne: podmioty, uwarunkowania prawne, potrzeby społeczne. P. Bieś-Srokosz (red.). Wrocław: Wydawnicwo Akademii im. Jana Długosza w Częstochowie.

Konstytucja Rzeczypospolitej Polskiej z dnia 2 kwietnia 1997 r., Dz.U. 1997.78.483 z pózn. zm.

Landau, Z. (1991). Podstawowe kierunki rozwoju ubezpieczeń społecznych, w: Rozwój ubezpieczeń społecznych w Polsce. C. Jackowiak (red). Wrocław: Wydawnictwo Zakład Narodowy im. Ossolińskich.

Lenio, P. (2018). Publicznoprawne źródła finansowania ochrony zdrowia. Warszawa: Wydawnictwo Wolters Kluwer.

Leowski, J. (2009). Polityka zdrowotna a zdrowie publiczne. Warszawa: Wydawnictwo CeDeWu.

Mahoney, C. (2010). Activating the Citizen: Dilemmas of Participation in Europe and Canada. West European Politics, 33(2): 400-402.

Makarzec, P. (2012). Ubezpieczenia społeczne w II Rzeczypospolitej. Zeszyty Naukowe WSEI 2(1): 197-210.

Miessen, M. (2013). Koszmar partycypacji. Warszawa: Bęc Zmiana.

Mikos, M., Urbaniak, M. (2016). Prawo do bezpiecznej ochrony zdrowia w świetle Konstytucji RP oraz rekomendacji Rady Europy i Rady Unii Europejskiej. Medyczna Wokanda, 8.

NIK (Najwyższa Izba Kontroli) (2019). System ochrony zdrowia w Polsce - stan obecny i pożadane kierunki zmian, https://www.nik.gov.pl/plik/id,20223, vp,22913.pdf (dostęp: 29.03.2019).

Olson, M. (1965). The Logic of Collective Action: Public Goods and the Theory of Groups. Cambridge: Harvard University Press.

Rabiej, E. (2017). Transformacja systemu ochrony zdrowia w Polsce - w drodze do zrównoważonego rozwoju, w: Finansowanie zadań publicznych w Polsce. Warszawa: Studia Biura Analiz Sejmowych Kancelarii Sejmu, 4(52).

Raport Stowarzyszenia Klon/Jawor. Kondycja organizacji pozarządowych w 2018 r., https:// fakty.ngo.pl/raporty/kondycja-organizacji-pozarzadowych-2018 (dostęp: 25.03.2019).

Skrzypczak, Z. (2013). Polski system ochrony zdrowia w okresie reformy na tle systemów europejskich, w: Fenomen transformacji. A. Nowak (red.). Warszawa: Wydawnictwo Naukowe Uniwersytetu Warszawskiego.

Sześciło, D. (2017). Zmierzch decentralizacji? Instytucjonalny krajobraz opieki zdrowotnej w Europie po nowym zarzadzaniu publicznym. Warszawa: Wydawnictwo Naukowe Scholar.

Urbaniak, M. (2013). Konstytucyjna zasada równego dostępu do świadczeń opieki zdrowotnej a jej ustawowa realizacja w prawie polskim. Przegląd Prawa Konstytucyjnego, 3(15): 79-98.

Wieloch, M. (2011). Kierunki zmian systemu ochrony zdrowia w Polsce, w: Kierunki rozwoju systemu ochrony zdrowia w Polsce. E. Nojszewska (red.). Warszawa: Oficyna Wydawnicza SGH. 


\section{Wywiady}

Na potrzeby niniejszej publikacji przeprowadzono kilkanaście wywiadów pogłębionych półustrukturyzowanych, z których wykorzystano jedenaście poniższych:

W/15/05/2019 - wywiad przeprowadzony 15 maja z prezesem największej organizacji parasolowej w Polsce

W/21/05/2019- wywiad przeprowadzony 21 maja z byłym członkiem organizacji parasolowej pacjentów funkcjonującej na poziomie unijnym

W/28/05/2019 - wywiad przeprowadzony 28 maja z prezesem największej organizacji parasolowej dedykowanej pacjentom z różnymi chorobami rzadkimi i jednocześnie ekspertem akademickim w zakresie systemów ochrony zdrowia

W/7/06/2019 - wywiad przeprowadzony 7 czerwca z członkiem organizacji zajmującej się problemami pacjentów z mięsakami

W/9/06/2019 - wywiad przeprowadzony 7 czerwca z członkiem organizacji zajmującej się diabetologią

W/12/06/2019 - wywiad przeprowadzony 12 czerwca z prezesem jednej z organizacji parasolowych w Polsce

W/12/06/2019/2- wywiad przeprowadzony 12 czerwca z prezesem organizacji zajmującej się jedną z chorób rzadkich

W/13/06/2019 - wywiad przeprowadzony 13 czerwca z prezesem organizacji zajmującej się jedną z chorób rzadkich

W/18/06/2019 - wywiad przeprowadzony 18 czerwca z prezesem organizacji zajmującej się jedną z chorób rzadkich

W/20/06/2019 - wywiad przeprowadzony 20 czerwca z członkiem organizacji zajmującej się onkologią ginekologiczną

W/28/06/2019 - wywiad przeprowadzony 28 czerwca z prezesem jednej z najstarszych organizacji parasolowych w Polsce

Publikacja powstała dzięki środkom w ramach międzynarodowego projektu badawczego pt. „Zorganizowane grupy interesów jako "brakujące ogniwo" w kreowaniu polityk w wybranych krajach postkomunistycznych" realizowanego przez Uniwersytet Opolski (Polska) oraz Uniwersytet w Konstancji (Niemcy) przy wsparciu finansowym Deutsche Forschungsgemeinschaft/Niemieckiej Fundacji Badawczej (DFG) i Narodowego Centrum Nauki (NCN). Projekt DFG-NCN/Beethoven, nr rej. 2016/23/G/HS5/01001. 